\title{
A Baseline Studies on the Nutritional Interplay between HIV Drugs and Kidney, Liver and Heart Indices in Patients Receiving HIV Treatment in North-East Nigeria
}

\author{
Nkereuwem Sunday Etukudoh'1, Adetunji Joshua ${ }^{2}$, Olowu Frederick Adeyemi ${ }^{3}$, \\ Joyce Ene Ocheola Oki ${ }^{*}$, Nathan Ukuoghene Ikimi ${ }^{5}$, Zira Sunday Peter ${ }^{6}$, Burba Rimamtsiwe Adi ${ }^{7}$ \\ ${ }^{1}$ Department of Haematology, Federal School of Medical Laboratory Science, Jos, Plateau State, Nigeria \\ ${ }^{2}$ Managing Director Medico Laboratory, Jos, Plateau State, Nigeria \\ ${ }^{3}$ Department of Medical Microbiology, Federal School of Medical Laboratory Science, Jos, Plateau State, Nigeria \\ ${ }^{4}$ Federal School of Medical Laboratory Science, Jos, Plateau State, Nigeria \\ ${ }^{5}$ Department of Chemistry, Adamawa State University, Mubi, Nigeria \\ ${ }^{6}$ Dental and Maxillofacial Surgery Department, State House Clinic, Abuja, Nigeria \\ ${ }^{7}$ Department of Home Economics, Faculty of Agriculture, Taraba State University, Jalingo, Nigeria \\ Email: *katejoshua@yahoo.com
}

How to cite this paper: Etukudoh, N.S. Joshua, A., Adeyemi, O.F., Oki, J.E.O., Ikimi, N.U., Peter, Z.S. and Adi, B.R. (2021) A Baseline Studies on the Nutritional Interplay between HIV Drugs and Kidney, Liver and Heart Indices in Patients Receiving HIV Treatment in North-East Nigeria. Food and Nutrition Sciences, 12, 848-857. https://doi.org/10.4236/fns.2021.128063

Received: July 8, 2021

Accepted: August 24, 2021

Published: August 27, 2021

Copyright $\odot 2021$ by author(s) and Scientific Research Publishing Inc. This work is licensed under the Creative Commons Attribution International License (CC BY 4.0).

http://creativecommons.org/licenses/by/4.0/ (c) (i) Open Access

\begin{abstract}
Human Immunodeficiency Virus (HIV) patients on Antiretroviral Therapy (ART) have shown impressive improvement and death rates have drastically reduced, even though complications still exist. This research carried out a baseline study to determine the nutritional interplay between HIV-drugs and kidney, liver, and heart indices among subjects undergoing HIV treatment and attending the Medical Out-Patient Department of a Federal Medical Center in the North-Eastern part of Nigeria, using a sample size of 50 individuals both male and female, who have been shown to be HIV positive and have been on ART for over 12 months. Anthropometric data was collected in triplicate, two from patients' file, and one was measured directly and the average was obtained. The electrolytes were determined by the colorimetric method while total protein and albumin in blood concentration were determined by spectrophotometric method, but globulin and A/G ratio were determined by calculation. TC was determined using Spectrophotometric method while HDL was determined after precipitation of LDL with phosphotungstate and magnesium were calculated from Friedwaldís formular, and TG was measured using the colorimetric enzymatic method. The results showed that the mean systolic and diastolic blood pressure which were $119.9 \mathrm{mmHg} \pm 17.5$, and 76 . $6 \mathrm{mmHg} \pm 10.1$ respectively, were with the range of the reference values. The
\end{abstract}


mean body mass index was $25.1 \pm 4.9$; also within range of the reference value. Major indices from the liver function test were mean ALT which was 36.5 \pm 29.4 with a reference value of $7-55 \mathrm{U} / \mathrm{L}$; AST was $40.0 \pm 32.3$, with a reference value of $8-48 \mathrm{U} / \mathrm{L}$. The mean value for albumin was $4.6 \pm 7.1$ with a reference range of $3.5-5.0 \mathrm{~g} / \mathrm{dl}$, these values also were within the reference range values. The electrolyte test showed all other electrolytes to be within the reference range values except for Zinc which was $19.5 \mu \mathrm{mol} / \mathrm{L}$, with a normal range of $70-100 \mu \mathrm{mol} / \mathrm{L}$ and magnesium which was found to be $0.7 \mathrm{mEq} / \mathrm{L}$, with a normal range of $1.5-2.0 \mathrm{mEq} / \mathrm{L}$; Zinc and magnesium play vital roles in over 300 enzymatic reactions, and are known to be important in the immune response. Shortfalls in these minerals could compromise the patients' recovery process and place them at risk of hearts conditions such as arrhythmia or heart attack among many other conditions. There is a need for an immediate review of these treatments in the direction of Zinc and magnesium, either by supplementation or by diet therapy. HIV patients undergoing ART should be placed under strict Zinc and magnesium-rich diet to avert untimely death among these patients. The controlled study should be done to ascertain the best approach to quell the residue of malnutrition in these patients in order to further improve their nutritional status.

\section{Keywords}

Human Immunodeficiency Virus (HIV), Antiretroviral Therapy (ART) Nutritional Status, Malnutrition, Diet

\section{Introduction}

Since the beginning of the HIV/AIDS epidemic, more than 70 million people have been infected with about 35 million deaths recorded [1]. As in 2019, 1.8 million people in Nigeria were living with HIV. Women were the most affected group counting about one million individuals [2]. While (United Nations Programme on HIV/AIDS: UNAIDS) puts its figures of people in Nigeria living with HIV at 1.9 million people in Nigeria [3]. The global HIV/AIDS pandemic, in most developing sub-Saharan countries especially in Nigeria is alarming, the proportion of people living with HIV, is potentially threatening, causing further reduction in life expectancy and overstressing the already weak health system.

Nigerias national HIV prevalence as at March 14, 2019 was 1.4\% among adults aged 15 - 49 yrs [4]. In Nigeria, 3.9\% of adults between ages $15-49$ are living with HIV/AIDS. Although the sero-prevalence rate of HIV is lower in Nigeria than in other African countries like South Africa or Zambia the size of Nigeria's population meant that by the end of 2006, there were estimated 2.9 Million infections with HIV with approximately 220,000 deaths, from HIV alone in 2006 [3]. With the introduction of HAART in the mid to late 1990s, HIV-associated morbidity and mortality in treated patients have significantly reduced so that they no longer succumb to opportunistic infections [5]. 
Human Immunodeficiency Virus (HIV) has been described as a linear single-stranded, enveloped RNA virus of the Retroviridae family which attacks immune cells called CD4 cells, which are types of T cells thereby causing Acquired Immunodeficiency Syndrome (AIDS) [6]. If left untreated, HIV infection usually progresses to AIDS. AIDS is a common condition which impacts reflectively on the ability of the body to combat infections. The virus is widely transmitted through contact of infected people with semen, virginal secretion, breast milk or blood of uninfected persons [7].

From the unset of reports, HIV infection has been attracting a lot of interest in its treatment and prevention. Currently, there is no known cure for HIV/AIDS but the use of antiretroviral drugs can help prevent secondary infections and complications while slowing down the disease's progression [8]. The antiretroviral drug is fast becoming a key instrument in the effective management of HIV.

Studies by Igwe [9] sought to evaluate the serum protein status and electrolyte profile of HIV/AIDS patients on Highly Active Anti Retroviral Therapy (HAART) in University of Port Harcourt Teaching Hospital (UPTH) Nigeria. The Method used for electrolytes determination was the colorimetric method while total protein and albumin concentration were determined by spectrophotometric methods, but globulin and $\mathrm{A} / \mathrm{G}$ ratio were determined by a simple calculation. In the study, a total of 50 randomly selected HIV males and females on HAART and 50 age/sex-matched HIV-seronegative volunteers were enrolled into the study. The study had as inclusion criteria: Positive testing to HIV antibody assay using an ACON HIV 1/2 Rapid Human Immunodeficiency Virus Test Strip and further confirmation of same using immunocomb HIV 1/2 Bio spot (Oregenics, Israel). Patients were also included if they were aged 18 - 50 years, and on HAART and if they indicated interest using their informed consent given through completing and signing of the informed consent form. At the end of the study, results obtained showed a significantly higher total protein $(\mathrm{p}<0.05)$ in male HIV patients on HAART when compared to the male non-HIV patients. For albumin, the result indicated a significantly lower value $(\mathrm{p}<0.05)$ in female and male HIV patients on HAART ( $2.38 \pm 0.22$ and $3.27 \pm 0.22 \mathrm{~g} / \mathrm{dL}$ respectively) when compared to the control. A/G ratio in male and female HIV patients on HAART was also significantly lower $(0.54 \pm 0.09$ and $0.69 \pm 0.09 \mathrm{~g} / \mathrm{dL})$ compared to the control. From the result, a significantly lower value $(\mathrm{p}<0.05)$ in the concentration of sodium of female and male HIV patients on HAART $(132 \pm 5.20 \mathrm{mMol} / \mathrm{L}$ and $136.12 \pm 4.85 \mathrm{mMol} / \mathrm{L}$ respectively) when compared to the control. The result for bicarbonate indicated a significantly lower value $(\mathrm{p}<0.05)$ in female HIV patients on HAART $(23.24 \pm 2.20 \mathrm{mMol} / \mathrm{L})$ than the males. Though the levels of most of the parameters analyzed were found within the normal range, serum protein and electrolyte monitoring in patients with HIV was recommended soon as treatment commences but notably this study did not veer into the nutritional interplay between the drugs and other indices especially Zinc and Magnesium which are very essential in boosting the patients' immunity to fight the 
disease. In a similar study by Nwauche [10], a comparative study on the electrolyte levels of HIV/AIDS patients on High Active Antiretroviral Therapy (HAART) in Owerri metropolis, South Eastern Nigeria was carried out. The study investigated and compared the electrolyte levels of HIV/AIDS patients on High Active Antiretroviral Therapy (HAART). In this study, thirty patients (13 males and 17 females) were recruited. Those included in this study were HIV positive and on high active anti-retroviral treatment for at least three months. They were not on any kind of mind-altering medications and were mentally sound and were within the age range of 10 years to 59 years. Remarkable differences were observed in the concentrations of the electrolytes $\left(\mathrm{Cl}^{-}, \mathrm{Na}^{+}, \mathrm{K}^{+}, \mathrm{HCO}_{3}^{-}\right)$when compared with their normal ranges. Decreased levels $(\mathrm{mmol} / \mathrm{L})$ of serum $\mathrm{Cl}^{-}(3.90 \pm 0.54)$ and $\mathrm{Na}^{+}(31.70 \pm 0.10)$ were observed. Between the male and female patients, $\mathrm{K}^{+}$ level $(\mathrm{mmo} / \mathrm{L})(3.70 \pm 0.54$ and $4.0 \pm 0.54$ respectively) was observed to be within the normal value of $3.5-5.0 \mathrm{mmo} / \mathrm{L}$. $\mathrm{Na}^{+}$concentration $(\mathrm{mmol} / \mathrm{L})$ was observed to be decreased in both males and females with the values of $130.80 \pm 6.40$ and $131.4 \pm 6.50$ respectively. The $\mathrm{Cl}^{-}$concentration $(\mathrm{mmol} / \mathrm{L})$ was observed to be increased in females $(98.40 \pm 7.60)$ and decreased in males $(97.20 \pm 8.90)$ when compared with the normal range $(98.00-105.00 \mathrm{mmol} / \mathrm{L})$. The study showed that the male patients were found to have a remarkable increase in the concentration $(\mathrm{mmol} / \mathrm{L})$ of their $\mathrm{HCO}_{3}^{-}(38.20 \pm 15.70)$ than the female counterpart $(25.10 \pm 2.60)$ when compared with the normal value of $24.00-30.00 \mathrm{mmol} / \mathrm{L}$ even though no known explanation was given for this. It was also noted that the concentration (mmol/L) of $\mathrm{Na}^{+}$of all the ages (10 - 59 years) was established to be diminished when compared with the normal range (135.00 - $150.00 \mathrm{mmol} / \mathrm{L})$, while $\mathrm{K}^{+}$for all the ages was observed to fall within the normal range. The age range of $30-39$ years exclusively had an increased level of $\mathrm{Cl}^{-}(145.90 \pm 48.10)$ while the other age ranges were diminished. It was also observed that the concentration $(\mathrm{mmol} / \mathrm{L})$ of $\mathrm{HCO}_{3}^{-}$of all the age ranges were established to be within the normal range excluding those with the age range of $20-29$ years, which was found to show a decreased concentration $(\mathrm{mmol} / \mathrm{L})$ of $22.30 \pm 4.00$ when weigh-up with the normal range of $24.00-30.00 \mathrm{mmol} / \mathrm{L}$. The study recommended strict and early monitoring of the serum electrolytes in HIV/AIDS patients on HAART, as this will prompt early detection and treatment if any anomalies are detected to enhance the quality of life of patients.

Although many studies have shown interest on the various indices as regards HIV and AIDS patients especially those receiving treatment with anti-retroviral drugs, with different continents, countries and even regions having varying results, not much is known about the nutritional interplay between the drugs (anti-retroviral drugs) and kidney, liver and heart indices especially in north-eastern Nigeria to be very precise. This timely work sets a center stage to checkmate these interplay, hence, the aim of this work is a baseline study on the nutritional interplay between HIV drugs and kidney, liver and heart indices in patients receiving HIV treatment. 


\subsection{Study Design}

The study is a cross sectional but experimental research by nature.

\subsection{Study Area}

A north eastern state in Nigeria was chosen for this research because apart from being one of the north eastern states ravaged by insurgency, the state also has quite a number of patients living with HIV and AIDS who are most likely to be cut off from researches such as this due to the prevailing situation of insurgency, banditry, kidnapping and other vices.

\section{Methods}

Fifty (50) HIV/AIDS patients (25 males and 25 females) aged 25 - 59 years drawn from patients attending Medical Out-patient Department of Federal Medical Center, of the north eastern state, were recruited for participation in the study out of which all fifty of them were chosen to participate. Patients included those whose HIV/AIDS status have been confirmed (Western blot), whether symptomatic or asymptomatic and were receiving ART. Excluded from the study were patients that with family history of kidney, liver, and heart disease. The purpose of the study was explained to the patients after which informed consent were obtained. Patients that were diabetic, hypertensive or have any other conditions that may interfere with the result were also excluded.

\subsection{Sample and Sample Collection Technique}

Case records of fifty (50) patients whose names were randomly selected from the clinic register were retrieved and reviewed for analysis. Information obtained from the case notes includes socio demographic characters, baseline anthropometric parameters like weight, height and Body mass index (BMI), baseline value of lipid profiles i.e. serum LDL, HDL, TG and TC, results of serological markers for HIV, for HBV i.e. Hepatitis B surface antigen (HBsAg) and for HCV I were collected for each of these fifty patients. Two different results were extracted for each parameter from the patients' case notes. After which socio demographic characters, baseline anthropometric parameters like weight, height and Body mass index (BMI) were again collected from each of the patients to check for variability and confirm data uniformity. Blood samples were then taken by venepuncture from the HIV/AIDS patients. Serum was prepared by centrifugation using MSE minor centrifuge model at $1500 \mathrm{rpm}$ for $5 \mathrm{~min}$. The serum samples were stored at $-20^{\circ} \mathrm{C}$ until needed for analysis.

\subsection{Determination of Plasma Electrolytes}

A $5 \mathrm{ml}$ portion of venous blood was collected from each subject by venupuncture and allowed to clot. This was later centrifuged in a Wisperfuge (Model 684) centrifuge at $2500 \mathrm{~g}$ for $5 \mathrm{~min}$ and then analyzed for the difference using the method of Igwe [9] page 90 of 93 parameters. Serum Albumin (ALB) was determined by 
the method of [11], serum total protein (TP) by the method of [12], serum globulin was calculated thus; serum globulin $=$ total protein - serum albumin $(\mathrm{TP}-$ ALB). A/G ratio was also by calculation and bicarbonate by titration as described by [12]. Serum sodium, potassium and chloride levels were determined by ion selective electrode method using Humalyte machine (Human, Germany) [12]. Chloride concentration was determined using the mercuric nitrate method while bicarbonate was assayed by back titration. Potassium and sodium were analyzed with the flame photometer [12].

\subsection{Lipid Profile}

Fasting venous blood sample drawn from consented subjects after adequate disinfection of the area was separated to obtain plasma which was then frozen stored till analyzed. TC was determined using ferricperchlorate method while HDL was determined after precipitation of LDL with phosphotungstate and magnesium was calculated from Friedwaldís formular LDL $=$ TCx HDL (TG/5) [13]. TG was measured using the colorimetric enzymatic method.

Each data for each patient was obtained in triplicate, and the average taken to minimize error.

\subsection{Statistical Analysis}

Results were analyzed using Statistical Package for Social Sciences (SPSS) version 20.0. The data were expressed using descriptive statistics and percentages. Values were given as mean and standard deviation.

\section{Results}

A baseline studies on the nutritional interplay between HIV drugs and kidney, liver and heart indices in patients receiving HIV treatment and the results obtained were as follows: (Table 1 and Table 2).

Table 1. Blood pressure and anthropometric parameters of the subjects.

\begin{tabular}{cccc}
\hline Parameter & Mean and SD & Normal/Average & Unit \\
\hline Blood Pressure (Systolic) & $119.9 \pm 17.5$ & $\leq 120$ & $\mathrm{~mm} / \mathrm{Hg}$ \\
Blood Pressure (Diastolic) & $76.6 \pm 10.1$ & $\leq 80$ & $\mathrm{~mm} / \mathrm{Hg}$ \\
Weight $(\mathrm{Kg})$ & $62.0 \pm 14.5$ & $60.7(\mathrm{AVG})$ & $\mathrm{Kg}$ \\
Height $(\mathrm{cm})$ & $157.9 \pm 86.9$ & $160-167(\mathrm{AVG})$ & $\mathrm{cm}$ \\
BMI & $25.1 \pm 4.9$ & $18.5-24.9$ &
\end{tabular}

Table 2. Table showing results of Liver Function Test (LFT), electrolyte, and lipid profile of the subjects.

\begin{tabular}{ccc}
\hline Analyte & Mean and SD & Reference Ranges \\
\hline Liver Function Test & & \\
ALT & $36.5 \pm 29.4$ & $(7-55 \mathrm{U} / \mathrm{L})$ \\
\hline
\end{tabular}




\section{Continued}

\begin{tabular}{|c|c|c|}
\hline AST & $40.0 \pm 32.3$ & $(8-48 \mathrm{U} / \mathrm{L})$ \\
\hline ALP & $129.1 \pm 34.6$ & $(40-129 \mathrm{U} / \mathrm{L})$ \\
\hline Total Protein & $78.9 \pm 13.3$ & $(62-80 \mathrm{~g} / \mathrm{L})$ \\
\hline ALBUMIN & $4.6 \pm 7.1$ & $(3.5-5.0 \mathrm{~g} / \mathrm{dl})$ \\
\hline Total Bilirubin & $1.1 \pm 9.4$ & $(0.1-1.2 \mathrm{mg} / \mathrm{dl})$ \\
\hline Direct Bilirubin & $8.8 \pm 5.7$ & \\
\hline \multicolumn{3}{|l|}{ Eletrolytes } \\
\hline Sodium & $140.7 \pm 11.6$ & $(134-145 \mathrm{mmol} / \mathrm{L})$ \\
\hline Pottassium & $4.2 \pm 0.6$ & $(3.5-5.5 \mathrm{mmol} / \mathrm{L})$ \\
\hline Chloride & $104.3 \pm 3.4$ & $(96-106 \mathrm{mmol} / \mathrm{L})$ \\
\hline Bicarbonate & $24.7 \pm 3.2$ & $(21-31 \mathrm{mmol} / \mathrm{L})$ \\
\hline Calcium & $2.3 \pm 0.2$ & $(2.1-2.6 \mathrm{mmol} / \mathrm{L})$ \\
\hline Zinc & $19.5 \pm 7.8$ & $(70-100 \mu \mathrm{mol} / \mathrm{L})$ \\
\hline Magnesium & $0.7 \pm 0.3$ & $(1.5-2.0 \mathrm{mEq} / \mathrm{L})$ \\
\hline Phosphate & $1.4 \pm 0.3$ & $(0.8-1.5 \mathrm{mmol} / \mathrm{L})$ \\
\hline UREA & $3.2 \pm 1.3$ & $(2.5-6.6 \mathrm{mmol} / \mathrm{L})$ \\
\hline Creatinine & $66.9 \pm 14.5$ & $(72-126 \mathrm{mmol} / \mathrm{L})$ \\
\hline \multicolumn{3}{|l|}{ Lipid Profile } \\
\hline T.CHOL & $4.49 \pm 3.5$ & $(3.5-6.0 \mathrm{mmol} / \mathrm{L})$ \\
\hline Trig & $2.10 \pm 1.0$ & $(0.59-1.75 \mathrm{mmol} / \mathrm{L})$ \\
\hline HDL & $1.83 \pm 0.1$ & $(0.39-1.83 \mathrm{mmol} / \mathrm{L})$ \\
\hline LDL & $2.21 \pm 1.3$ & $(2.58-4.89 \mathrm{mmol} / \mathrm{L})$ \\
\hline RBS & $5.4 \pm 1.7$ & \\
\hline
\end{tabular}

\section{Discussion}

A baseline studies to determine the nutritional interplay between HIV-drugs and kidney, liver, and heart indices, was carried out with subjects undergoing treatment in the North Eastern Nigeria, using a sample size of 50 individuals both male and female, who have been shown to be HIV positive and have been on ART for over 12 months.

The study was carried out using a simple random sampling method which took into consideration multiple index values of the entire required variable, with the consents of the subjects, samples were taken as well as their anthropometric indices, with the aim of understanding the nutritional inter-play alongside determining nutrient deficits if any.

The results showed that the mean systolic blood pressure was $119.9 \mathrm{mmhg} \pm$ 17.5, while the mean diastolic blood pressure was $76.6 \mathrm{mmhg} \pm 10.1$. The mean weight was $62.0 \mathrm{~kg} \pm 14.5$, mean height was $157.9 \mathrm{~cm} \pm 86.9$, while the mean body mass index was $25.1 \pm 4.9$; as seen in Table 1 , so far, these values were 
within the reference value range for both male and females who participated in the research.

Inquiry on the Liver Function Test, (LFT) indices shows that the mean value for ALT was $36.5 \pm 29.4$ with a reference value of $7-55 \mathrm{U} / \mathrm{L}$, AST was $40.0 \pm$ 32.3 , with a reference value of $8-48 \mathrm{U} / \mathrm{L}$. Mean value for albumin was $4.6 \pm 7.1$ with a reference range of $3.5-5.0 \mathrm{~g} / \mathrm{dl}$.

For the electrolytes, mean values showed that sodium was $140.7 \mathrm{mmol} / \mathrm{L}$, with a normal range of $134-145 \mathrm{mmol} / \mathrm{L}$; potassium was $4.2 \mathrm{mmol} / \mathrm{L}$, with a normal range of $3.5-5.5 \mathrm{mmol} / \mathrm{L}$; bicarbonate was $24.7 \mathrm{mmol} / \mathrm{L}$, with a normal range of $21-31 \mathrm{mmol} / \mathrm{L}$; calcium was $2.3 \mathrm{mmol} / \mathrm{L}$, with a normal range of $2.1-2.6 \mathrm{mmol} / \mathrm{L}$ all of which were within range of their normal values; Zinc was $19.5 \mu \mathrm{mol} / \mathrm{L}$, with a normal range of $70-100 \mu \mathrm{mol} / \mathrm{L}$; this can be seen in Table 2 this falls far below the normal range, this agrees with the works of [14] Remedevi, which showed that HIV infected patients on treatment are malnourished and deficient of Zinc. Magnesium was found to be $0.7 \mathrm{mEq} / \mathrm{L}$, with a normal range of $1.5-2.0 \mathrm{mEq} / \mathrm{L}$; this also is far below normal and magnesium is known to participate in over 300 enzymatic reactions in the body. Phosphate was $1.4 \mathrm{mmol} / \mathrm{L}$, with a normal range of 0.8 - $1.5 \mathrm{mmol} / \mathrm{L}$; urea was $3.2 \mathrm{mmol} / \mathrm{L}$, with a normal range of 2.5 - 6.6 $\mathrm{mmol} / \mathrm{L}$; while creatinine was $66.9 \mathrm{mmol} / \mathrm{L}$ with a normal range of $72-126$ $\mathrm{mmol} / \mathrm{L}$. Phosphate, urea and creatinine were within range of normal values.

The electrolyte values showed that all other values were within range of their reference except for Zinc, which was by far below the reference value $19.5 \mathrm{~mol} / \mathrm{L}$ as compared to the reference value of $70-100 \mu \mathrm{mol} / \mathrm{L}$. Notably Zinc is required more to boost the immune system, this means that the immune systems can be gravely compromised. Zinc is known to participate in over 300 enzyme activities in the body, Zinc keeps the immune system strong and supports normal growth. Low Zinc during infection may lead to excessive inflammation which may lead to instant death of cells. According to [15] BAUM, adequate Zinc is needed for T-cell division, maturation, differentiation, lymphocytes response to mitogen. Zinc also plays a role in gene transcription, and biomembrane functions. Zinc is also known to inhibit the production of tumour necrosis factor, which is implicated in the pathophysiology of cachexa and wasting in AIDS.

Apart from this, magnesium also was below reference value; $0.7 \mathrm{mEq} / \mathrm{L}$ was obtained as compared to a reference value of $1.5-2.0 \mathrm{mEq} / \mathrm{l}$. Magnesium acts as a co-factor for more than 300 enzymes in the body including binding ATP for kinase reactions, affects permeability of excitable membranes and neuromuscular transmission. Studies have shown that patients with GIT disease, Type II Diabetes, older adults, alcoholics, people with Crohns and Celiac disease are more at risk of magnesium depletion and deficiency. Magnesium is a natural calcium channel blocker, and an antagonist for sodium. Hence, low levels of magnesium could lead to Congestive Heart Failure (CHF), Ventricular Tachycardia (VT), as well as Ventricular Fibrillation (VF). This can cause increased production of Reactive Oxygen Species (ROS) or free radicals. Magnesium deficiency is believed to 
result from elevated circulatory levels of catecholamine, aldosterone and vasopressin as well as increased urinary magnesium excretion. Magnesium plays vital roles in antiviral and anti-tumor immunity.

Query on the lipid profile showed that total cholesterol was 4.49, triglycerol was 2.10 , HDL was $1.83 \mathrm{mmol} / \mathrm{L}$, LDL was $2.21 \mathrm{mmol} / \mathrm{L}$, RBS was 5.4 , of all the lipid profile indices, triglyceride value was above the reference value of $1.75 \mathrm{mmol} / \mathrm{L}$ while LDL was below the optimal value of $2.58 \mathrm{mmol} / \mathrm{L}$.

\section{Conclusion}

This baseline studies has been able to pick out a negative balance as it concerns micronutrients Zinc and magnesium among patients taking anti retroviral treatment. Zinc and magnesium have been well established to play vital roles in numerous enzymatic reactions in the human body as well as help boost patient's immune responses. Therefore, there is a need for an updated review in treatment regimen in the direction of Zinc and magnesium, with an imperative need for nutritional intervention in order to improve patients' nutritional status, and enhancing patient's quality of life. Professionals in the medical fields, and nutritionists and dietitians need to come together to help proffer practical solution to this imbalance during treatment among patients undergoing HIV treatment with anti retroviral drugs.

\section{Recommendations}

1) Similar baseline studies should be replicated and the results compared.

2) Immediate nutritional interventions should commence as soon as possible to avert increased death rate, which can be avoided.

\section{Conflicts of Interest}

The authors declare no conflicts of interest regarding the publication of this paper.

\section{References}

[1] UNAIDS (Joint United Nations Programme on HIV/AIDS) (2019) Global HIV \& AIDS Statistics-2019 Fact Sheet. https://www.unaids.org/en/resources/fact-sheet

[2] http://www.statistica.com

[3] UNAIDS (2008) Nigeria Country Profile.

[4] UNAIDS (Joint United Nations Programme on HIV/AIDS) (2019) Press Release of a New Survey Results Indicate That Nigeria Has an HIV Prevalence of $1.4 \%$. https://www.unaids.org/en/resources/presscentre/pressreleaseandstatementarchive/ 2019/march/20190314_nigeria

[5] Priscilla, Y., Hsue, M.D., David, D. and Waters, M.D. (2005) What a Cardiologist Needs to Know about Patient with HIV Infection. Circulation, 112, 3947-3957. https://doi.org/10.1161/CIRCULATIONAHA.105.546465

[6] Zhang, Y.Z., Li, H.J., Cheng, J.L., Wu, H. and Bao, D.Y. (2011) Computed Tomographic Demonstrations of HIV Seropositive Pulmonary Tuberculosis and Their 
Relationship with CD4+ T-Lymphocyte Count. Chinese Medical Journal, 124, 693-698.

[7] Schwartz, S.A. and Nair, M.P.N. (1999) Current Concepts in Human Immunodeficiency Virus Infection and AIDS. Clinical and Diagnostic Laboratory Immunology, 6, 295-305. https://doi.org/10.1128/CDLI.6.3.295-305.1999

[8] World Health Organisation (2019) Newsroom Fact Sheet on HIV/AIDS for 25th July 2019. https://www.who.int/news-room/fact-sheets/detail/hiv-aids

[9] Igwe, K.O., Ujowundu, C.O., Chieme, S.C. and Obasi, U.K. (2020) Serum Protein Status and Electrolyte Profile of HIV/AIDS Patients on HAART in UPTH, Rivers State-Nigeria. African Journal of Biological Sciences, 2, 88-93. https://doi.org/10.33472/AFJBS.2.3.2020.88-93

[10] Nwauche, K.T., Agomuo, E.N., Anacletus, F.C. and Nwosu, G.U. (2019) Comparative Study on the Electrolyte Levels of HIV/AIDS Patients on High Active Antiretroviral Therapy (HAART) in Owerri Metropolis, South Eastern Nigeria. International STD Research \& Reviews, 8, 1-5. https://doi.org/10.9734/ISRR/2019/v8i230101

[11] Doumas, B.T., Watson, W.A. and Biggs, H.G. (1971) Albumin Standards and the Measurement of Serum Albumin with Bomocresol Green. Clinica Chimica Acta, 31, 87-96. https://doi.org/10.1016/0009-8981(71)90365-2

[12] Tietz, N.W. (1987) Fundamentals of Clinical Chemistry. 3rd Edition, W.B. Saunders Company, Philadephia, 1010.

[13] Friedwald, W.T., Levy, R.I. and Frederickson, D.S. (1972) Estimationof the Concentration of Low Density Lipoproteincholesterol in Plasma without Use of Preparative Ultracentrifugation. Clinical Chemistry, 18, 499-502. https://doi.org/10.1093/clinchem/18.6.499

[14] Bhimavarapu, R., Chitra, K.P., Ramaswamy, M., Karunakaran, P., Reddy, A.B. and Rani, B.S. (2010) Nutritional Status and Serum Zinc Levels in HIV Infected Individuals Compared to Control Subjects Undergoing Anti Retro Viral Therapy (ART). Journal of Pharmaceutical Sciences and Research, 2, 745-751.

[15] Baum, M.K., Shor-Posne, G. and Campa, A. (2000) Zinc Status in Human Immunodeficiency Virus Infection. Journal of Nutrition, 130, 1421S-1423S. 